\title{
Griseofulvin in Leprosy
}

\author{
W. H. KNEEDLER \\ Formerly of McKean Leprosy Hospital, Chieng Mai, Thailand $\dagger$ \\ A controlled trial of Griseofulvin showed that the drug had no apparent beneficial \\ effect in patients with lepromatous leprosy.
}

\section{INTRODUCTION}

The present study of the action of Griseofulvin in leprosy was undertaken because previous trials must for various reasons be adjudged unsatisfactory; moreover, they produced conflicting results.

\section{MATERIALS AND METHODS}

\section{Selection of patients}

All 120 patients included in the trial were suffering from lepromatous or borderline-lepromatous leprosy and were in-patients at the McKean Leprosy Hospital, Chieng Mai. The 60 patients given Griseofulvin were paired as closely as possible with 60 control patients on the basis of age, sex, duration of disease, tendency to erythema nodosum leprosum (ENL), clinical activity of the leprosy, bacterial index, and type of treatment received.

\section{Bacterial status}

All the patients had a bacterial index (BI) of at least 1.25 at the beginning of the study, and in 16 of them it ranged from 1.25 to 2.50 ; initially all the patients had had a BI of 3.0 or higher except 3 in whom it was between 2.25 and 2.50 .

Age

All the patients but one were over 12 years of age.

\section{Supervision}

Regular clinical examinations and charting of lesions were under the personal supervision of the author. The trial was double-blind.

*Received for publication December, 1969.

†Present address: 865 North Church St., Concord, N. Carolina, 28025, U.S.A.
Dose of Griseofulvin

Griseofulvin was given in a dosage of $2 \times$ $0.5 \mathrm{~g}$ tablets daily (fine particle) for 3 months, and then 3 similar tablets daily thereafter. Two patients who could not tolerate the higher dose continued taking only 2 tablets daily.

\section{Duration of trial}

This was actually $8 \frac{1}{2}$ months. The original protocol had provided for the trial to last 12 months, but the interim results at $8 \frac{1}{2}$ months indicated that prolongation of the trial after this time would not be justified.

\section{Anti-leprosy drugs}

These were taken without interruption at the same dose as that before starting the trial with Griseofulvin. Dapsone was the usual drug, taken in a dosage of $100 \mathrm{mg} 3$ times weekly. Other drugs being administered, such as sulphetrone (by injection), thiacetazone, thiambutosine, or isoniazid (with or without streptomycin) were continued. The 60 control patients received a placebo of identical appearance and taste.

This report is based on the findings in the 9:3 patients who remained in McKean Hospital throughout the period of the study, that is, 43 taking Griseofulvin and 50 taking the placebo.

\section{RESULTS}

No significant differences could be detected between the patients taking the trialdrugand those taking the placebo under any of the following heads: bacterial index, granularity index, development of erythema nodosum leprosum, or clinical activity of the disease. 


\section{DISCUSSION}

In this study, Griseofulvin was given for a longer time and at a higher dose than in any previous study. The number of patients taking the drug was equal to the combined totals of those in trials previously reported. The present study was double-blind and carefully controlled, whereas only one previous report included controls-and that was a small series of 6 . It is noteworthy that the addition of Griseofulvin to standard therapy had no effect in accelerating either the rate of disappearance of morphologically normal Mycobacterium leprae or the reduction in the bacterial index.

\section{CLINICAL FINDINGS}

No evidence of improvement in the general clinical condition of any patient attributable to Griseofulvin was noted. In regard to erythema nodosum leprosum, 32 patients had none at any time during the period of the trial. No significant differences were seen in patients taking Griseofulvin compared with those in the control group.

On the other hand, the patients' own assessments of their subjective improvement during the period of the trial indicated that those in the control group reported a greater degree of inmprovement than those taking Griseofulvin.

\section{SUMMARY}

A double-blind trial of Griseofulvin as an adjunct to the standard treatment of 4.3 patients with lepromatous leprosy (compared with 50 similar patients receiving a placebo) provided no evidence that the addition of Griseofulvin accelerated bacillary destruction or bacillary clearance, or resulted in more rapid clinical improvement than was to be expected.

\section{ACKNOWLEDGEMENTS}

I wish to express appreciation of the help afforded by Messrs. Glaxo Ltd. in making available adequate supplies of both Griseofulvin and placebo tablets, and by Dr. E. S. Snell (Medical Director) and Mrs. P. S. Keen. I also wish to thank Dr. S. G. Browne, o.B.E., Director of the Leprosy Study Centre, London, for his interest and advice.

\section{REFERENCES}

BILE, T. (1963). Griseofulvin y lepra. Jerm. tr•p. 2, 204. PFALTZGRAFF, R. E. and COCHRANE, R. G. (1963). Limited pilot trial: Treatment of leprosy by Griseofulvin. Lepr. Rev. 34, 5 .

RAMASOOTA, T. (1964). Preliminary trial of Griseofulvin in the treatment of leprosy. .J. med. Ass. Thailand 47,495 .

SILVA, J. R. (1964). Sobre a possibilidade do emprego da Griseofulvina no tratamento de certos casos de lepra. O Hospital, Rio de .Janeiro 66, 9.

wolinsky, E. (1963). Modern treatment of mycobacterial diseases. Med. Clins N. Am. 46, 1273. 